\title{
REGULASI PERWAKAFAN DI INDONESIA DALAM PERSPEKTIF STATUTE APPROACH
}

\author{
Kama Mir'atul Chasanah*(a.1) Ghufron Maksum*(b.2) \\ Sekolah Pascasarjana UIN Syarif Hidayatullah Jakarta \\ Sekolah Tinggi Agama islam Nurul Iman
}

1 kama.miratul20@mhs.uinjkt.ac.id* 2 ghufronmaksum@stai-nuruliman.ac.id*

\begin{abstract}
Abstact
The potential of waqf in Indonesia, if managed properly, can be the most appropriate instrument to solve social Received: problems, especially in dealing with poverty. Waqf 03-12-2021

Revised:

09-12-2021

Published:

28-12-2021 regulation in Indonesia has experienced a long dynamic, starting from pre-independence, post-independence until now. This paper aims to explain waqf regulations in Indonesia from the perspective of the statute approach. This study is included in the category of library research with primary sources in the form of laws and government regulations relating to waqf, while secondary sources in the form of journals, books and others related to the theme of discussion. The data obtained were described and then analyzed. This paper finds that: 1) The emergence of various waqf regulations after Indonesia's independence is full of regulations that are able to balance between Islamic and positive laws that apply in Indonesia. 2) Regulation of waqf in Indonesia started from Law Number 5 of 1960 concerning Agrarian Principles, Presidential Instruction of the Republic of Indonesia Number 1 of 1991 concerning KHI, Law Number 41 of 2004, then Government Regulation Number 42 of 2006.

3) Law Number 41 of 2004, is a new breakthrough in the waqf management system in Indonesia to become productive waqf.
\end{abstract}

Keywords: Regulation, Waqf, Constitution

Abstrak Potensi wakaf di Indonesia jika dikelola secara tepat, dapat menjadi instrument yang paling tepat untuk menyelesaikan problem social, khususnya dalam menangani kemiskinan. Regulasi perwakafan di

Diterima: Indonesia mengalami dinamika yang panjang, mulai 
03-12-2021

Direvisi:

09-12-2021

Dipublikasi:

13-01-2022

dari pra-kemerdekaan, pasca-kemerdekaan hingga sekarang. Tulisan ini bertujuan untuk menjelaskan regulasi perwakafan di Indonesia dilihat dari perspektif pendekatan undang-undang (statute approach). Kajian ini masuk dalam kategori kajian kepustakaan (library research) dengan sumber primer berupa undang-undang serta peraturan pemerintah yang berkenaan dengan perwakafan, sedangkan sumber sekunder berupa jurnal, buku dan yang lainnya yang berkaitan dengan tema pembahasan. Data yang didapatkan dideskripsikan kemudian dianalisis. Tulisan ini menemukan bahwa: 1) Munculnya berbagai peraturan wakaf pasca kemerdekaan Indonesia sarat adanya regulasi yang mampu menyeimbangkan antara hukum Islam dan positifyang berlaku di Indonesia. 2) Regulasi perwakafan di Indonesia dimulai dari UU Nomor 5 tahun 1960 tentang Pokok Agraria, Instruksi Presiden Republik Indonesia Nomor 1 Tahun 1991 tentang KHI, UU Nomor 41 tahun 2004, kemudian peraturan Pemerintah Nomor 42 tahun 2006. 3) UU Nomor 41 tahun 2004, merupakan terobosan baru dalam system pengelolaan perwakafan di Indonesia menjadi wakaf produktif.

\section{Katakunci : Regulasi, Wakaf, Undang-undang}

\section{PENDAHULUAN}

Islam adalah agama rahmatan lil alamin yang mengatur hubungan manusia dengan Tuhannya maupun hubungan antar sesama umat bahkan sesama makhluk-Nya. Islam tidak hanya mengajarkan etis-normatif saja, akan tetapi memiliki kepekaan social serta mengajarkan keadilan serta memberikan arahan dalam kehidupan sosial kemasyarakatan. Salah satu pranata keagamaan dalam Islam adalah wakaf.

Wakaf adalah salah satu bentuk ibadah sunah yang mempunyai nilai khusus dalam pandangan islam, karena merupakan jenis ibadah secara vertikal, artinya berhubungan 
langsung kepada Allah, juga merupakan ibadah yang bersifat horizontal menyangkut kemaslahatan ummat manusia. Allah SWT berfirman dalam Q.S Ali-Imran (3): 92

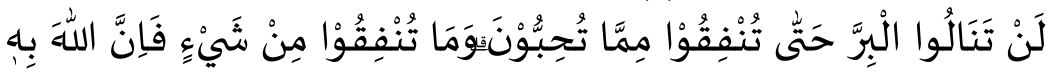
عَلِيْنَ

"kamu tidak akan memperoleh kebajikan, sebelum kamu menginfakkan sebagian harta yang kamu cintai. Dan apapun yang kamu infakkan tentang hal itu sungguh Allah Maha Mengetahui."

Selain itu, Wakaf merupakan ibadah maliyah yang sudah sangat dikenal mempunyai nilai sosial yang merupakan bagian dari amal jariyah dimana pahalanya akan terus mengalir selama harta yang diwakafkan tersebut masih dimanfaatkan oleh umat. ${ }^{1}$ Rasulullah SAW Bersabda:

عن ابي هريرة أن رسول الله صلى الله عليه وسلم قال : اذا مات الانسان انقطع عناه عمله الا من ثلاثة : الا من صدقة جارية او علم ينتفع باه او

$$
\text { ولد صالح يدعو له (رواه مسلم) }
$$

"Dari Abu Hurairah r.a bahwasanya Rasulullah SAW bersabda: "jika seorang manusia meninggal maka terputuslah seluruh amalnya, kecuali tiga perkara: sadaqah jariyah, ilmu yang bermanfaat dan anak shalih yangmendoakannya." (HR. Muslim) ${ }^{2}$

Di Indonesia, wakaf sudah dikenal sejak zaman dahulu sejalan dengan perkembangan Islam dan penyebarannya dengan pengelolaan seputar tempat ibadah seperti masjid, mushola dan gedung pesantren. Pemanfaatan wakaf masih terbatas pada benda-benda yang bersifat baqa'u ainuhu

1 Asni, "Pengembangan Hukum Perwakafan di Indonesia", Jurnal Al'Adl, vol.7 No.2, Juli 2014

${ }^{2}$ Imam Muslim, Shabih Muslim (Surabaya:al-Haramain,tt), hlm. 68 
artinya berupa wujud benda yang tetap atau tidak bergerak. ${ }^{3}$ Pengelolaan awal wakaf masih berlandaskan pada hukum fikih konvensional.

Diantara faktor terpenting dalam mewarnai corak perkembangan wakaf di Indonesia adalah ketika negara mampu mengambil posisi sebagai badan legislasi yang mampu mengatur kebijakan wakaf melalui seperangkat hukum positif. Perumusan kebijakan tersebut dapat terlihat dari potensi pengelolaan wakaf oleh pemerintah yang berkuasa serta visi dan misi kebijakannya dalam mengelola kepentingan umat. ${ }^{4}$

Untuk mengoptimalkan pelaksanaan wakaf sebagai dimensi ibadah mahdzoh yang bernilai sosial, perlu adanya regulasi hukum yang senantiasa mengikuti perkembangan zaman tanpa meninggalkan normatif hukum maupun landasan utama dari adanya ibadah tersebut. Sejauh ini, pemerintah Indonesia sudah memfasilitasi perundangundangan terkait wakaf bahkan merambah pada ranah yang mulai menuju pada pengaturan wakaf produktif, serta wakaf tunai yang sejatinya sudah dipraktikkan pada masa al-Zuhry (w.124 H) yang membolehkan wakaf dengan dinar maupun dirham dan kemudian menginisiasi fatwa MUI pada tahun 2002 yang memperbolehkan adanya wakaf uang (Cash Waqf). Fenomena-fenomena yang muncul seiring dengan lahirnya paradigma baru tentang perwakafan yang merupakan institusi amal sekaligus instrumen pembangunan sosial dan pemberdayaan ekonomi semakin ditopang dengan undangundang positif di Indonesia.

Kajian tentang wakaf memang sudah banyak dilakukan oleh para pengkaji, setidaknya dapat

3 Abu Syuja' Ahmad al-Asfahani, Ghayah wa at-Taqrib, (Semarang: CV. Toha Putra, tt), hlm. 39

${ }^{4}$ Sholikhul Hadi, Regulasi UU NO 41 tahun 2004 tentang wakaf, Jurnal Penelitian, vo 1.8, Agustus 2014, hlm. 320

Tasyri': Journal of Islamic Law, 
dikelompokan menjadi 3 tema: 1) kajian wakaf dilihat dari perspektif sejarah, mulai dari klasik hingga modern. ${ }^{5}$ 2) kajian wakaf dilihat dari pembaharuan objeknya. ${ }^{6}$ 3) kajian wakaf dilihat dari pengawasan nadzir.7 4) kajian wakaf dilihat dari sisi implementasi atau pengelolaanyanya ${ }^{8}$ dan 5) kajian wakaf dilihat dari sisi legalitas penukarannya. ${ }^{9}$ Oleh karena itu, tulisan ini dimaksudkan untuk mengisi kekosongan kajian wakaf tentang regulasinya di Indonesia.

\section{METODE}

Penelitian ini merupakan model penelitian hukum normative (doctrinal), dengan jenis penelitian library research (kepustakaan) dan menggunakan pendekatan kualitatif. Sumber data primer diperoleh dari salinan undang-undang no. 41 tahun 2004, peraturan pemerintah Nomor 42 Tahun 2006, dan beberapa undang-undang serta peraturan pemerintah yang terkait dengan persoalan wakaf. Sedangkan sumber data sekunder berupa buku, artikel jurnal yang berkaitan dengan tema pembahasan. Data yang diperoleh dianalisis dengan menggunakan teknik deskripstif analisis,

${ }^{5}$ Choirun Nissa, "Sejarah, Dasar Hukum Dan Macam-Macam Wakaf”, Tazkiya Jurnal Keislaman, Kemasyarakatan \& Kebudayaan, Vol. 18 No. 2 (JuliDesember) 2017

${ }^{6}$ Nugroho Heri Pramono, Merlina, dan Wiji Astuti, “Cerdas Bersama Wakaf (Cb Wakaf): Strategi Dan Inovasi Pengelolaan Wakaf Uang Di Era Digital”, Jurnal Sains Manajemen, Volume 5 No. 2 Desember 2019.

${ }^{7}$ Farid Rifai, "Analisis Sistem Pengawasan Wakaf di Indonesia", dalam PROCEEDINGS 1st ANNUAL CONFERENCE ON IHTIFAZ: Islamic Economics, Finance, and Banking 117 (ACI-IJIEFB) 2020

${ }^{8}$ Nanda Suryadi1 \& Arie Yusnelly, "Pengelolaan Wakaf Uang Di Indonesiasyarikat:", Jurnal Rumpun Ekonomi Syariah, Volume 2 Nomor 1, Juni 2019

9 Atep Hendang Waluya, Istibdal Wakaf Dalam Pandangan Fukaha Klasik Dan Kontemporer, dalam MISYKAT AL-ANWAR, Jurnal Kajian Islam Dan Masyarakat, https://jurnal.umj.ac.id/index.php/MaA16/index Volume 29, No 2, 2018 
dimana data-data tersebut didiskripsikan kemudian dianalisis dengan menggunakan teori Miles and Hubermen, yaitu reduksi data, penyajian data dan penarikan kesimpulan.

\section{PEMBAHASAN}

\section{A. Wakaf Dalam Lintasan Sejarah Indonesia}

Usaha untuk mentransformasikan fiqih Islam kedalam per-undang-undangan berupa hukum positif melalui proses taqnin sudah berlangsung cukup lama terutama dapat dilihat pada awal diundangkannya masalah perkawinan melaui UU NO.1 tahun 1974, kemudian PP NO. 28 tahun 1977 tentang perwakafan dan menyusul undang-undang lain serta lahirnya Kompilasi Hukum Islam. ${ }^{10}$

Apabila melihat sejarah perkembangan regulasi wakaf di Indonesia Dari masa pra kemerdekaan hingga saat ini, dapat diamati dari karakternya seperti memiliki kesamaan tujuan. Di Banten ada istilah "Huma Serang" yang merupakan ladang-ladang dimana pengelolaannya secara bersama-sama serta digunakan untuk kepentingan bersama. Di Lombok juga ada istilah "Tanah Pareman" yang merupakan tanah Negara yang dibebaskan dari pajak, "Landrette". Hasil dari tersebut diserahkan ke desa-desa, subak dan Candi untuk kepentingan umum. Adapun diwilayah Jawa sendiri tepatnya di Jawa Timur ada istilah tanah "Perdikan" yang merupakan tanah pemberian Raja kepada seseorang atau sekelompok orang yang telah berjasa. Tanah ini mempunyai kemiripan dengan wakaf ahli (wakaf untuk keluarga) dari segi fungsi dan pemanfaatannya, tanah perdikan pun tidak boleh dijual belikan. ${ }^{11}$ Dari sinilah dapat dsimpulkan bahwa wakaf di Indonesia memiliki corak yang

10 HE. Syibli Syarjaya, Perkembangan Perwakafan dalam perundangundangan di Indonesia, Jurnal Al-Qalam vol.26 No.2 (Mei-Agustus 2009)

11 Achmad Djunaidi dkk, Perkembangan Pengelolaan Wakaf Di Indonesia, (Jakarta: Direktorat Pemberdayaan Wakaf, 2006), hlm. 13 
khas sesuai daerahnya dan secara umum sesuai dengan hukum perwakafan menurut syariat Islam.

Untuk melihat perkembangan perundang-undangan perwakafan yang melalui proses panjang sampai kepada undang-undang No. 41 tahun 2004 dapat dirunut sebagai berikut:

\section{Perwakafan Pra -kemerdekaan Indonesia}

Pewakafan tanah telah dikenal masyarakat muslim pada abad ke XV di Jawa timur dengan adanya Masjid Raden Rahmat dan pesantren di Ampel Denta Surabaya ${ }^{12}$ kemudian ada juga temuan-temuan istilah perwakafan yang berkembang tahun 1922 sepanjang daerah Aceh, Gayo, Tapanuli, Jambi, Palembang, Bengkulu, Banten, Jawa Tengah, Jawa Timur, Minahasa, Gorontalo bahkan sampai Lombok dengan istilah yang berbeda-beda dengan esensi yang sama mulai dari benda yang diwakafkan berupa sawah, tanah kering, masjid, surau, perkebunan, batu bata bahkan AlQur'an dan sajadah. ${ }^{13}$

Selain masyarakat muslim, kaum adat juga mengenal istilah serupa dengan wakaf seperti Pusaka Tinggi dan Rendah pada masyarakat Minangkabau, tanah-tanah yang dipakai oleh masyarakat Bali untuk upacara Ngaben, tanah Pareman oleh masyarakat Lombok, tanah perdikan dan desa Pekuncen dikalangan kerajaan Jawa sebagai tanah yang diperuntukkan untuk para keluarga juru kunci kerajaan, yang semua jenis tanah tersebut terbebas dari pajak dan lama kelamaan berfungsi seperti tanah wakaf. ${ }^{14}$

${ }^{12}$ Rahmat Djatnika, Pandangan Islam tentang Infak, Shadaqah, Zakat dan Wakaf (Surabaya: al-Ikhlas, 1982), hlm. 20

13 Imam Suhadi, Wakaf untuk Kesejahteraan Umat, (Yogyakarta:PT. Dana Bakti Prima Yasa,2002), hlm. 39

14 Surjono Sokanto, Hukum Adat Indonesia, Jakarta: CV. Rajawali, 1981), hlm. 292 
Eksisnya kelembagaan wakaf di permulaan abad ke-19 dengan lahirnya pesantren-pesantren di Jawa dan Sumatera, membuat pemerintah Kolonial Belanda mengeluarkan pranata perwakafan yang belum dapat menyentuh esensi wakaf secara islami, karena hanya sebatas berkaitan dengan tata letak pertanahan. Diantara surat edaran yang mereka keluarkan adalah:

a. Surat edaran Sekretaris Governemen tanggal 31 Januari 1905, No. 435 yang dimuat dalam_Bijblad 1905 No. 435, sebagaimana termuat dalam Bijblad 1905 Nomor 6196,tentang Toezicht op den Bouw van Mohammedaansche bedehuizen.

Surat edaran ini ditujukan kepada kepala wilayah Jawa dan Madura dalam hal ini bupati, untuk mencatat semua daftar rumah ibadat di kabupaten masingmasing.

b. Surat edaran Sekretaris Governemen tanggal 4 Juni 1931 NO. 1361/A yang dimuat dalam Bijblad 1931 NO. 125/3 tentang Toezich van de regeering op Mohammedaansche bedebuizen, vrijdagdiensten en Wakaps yang menegaskan agar edaran tahun 1905 benar-benar diperhatikan. Para bupati agar mencatat dan menyusun daftar rumah-rumah ibadat, penggunaannya untuk shalat jum'at atau tidak, dan perolehan tanahnya apakah dari wakaf atau bukan.

c. Surat Edaran Sekretaris Governemen tanggal 24 Desember 1934 NO. 3088/ A yang dimuat dalam Bijblad 1934 NO. 13390 masih tentang materi yang sama dan bentuk penegasan pada edaran sebelumnya. Dan ada kewenangan bagi Bupati untuk ikut andil sebagai mediator dalam menyelesaikan perkara perwakafan.

d. Surat Edaran Sekretaris Governemen tanggal 27 Mei 1935 No. 1273/A yang dimuat dalam Bijblad 1935 NO. 13480 tentang penguatan terhadap edaran-edaran sebelumnya. 
Regulasi hukum perwakafan pada masa kolonial ini dapat disimpulkan sebagai peraturan tentang wakaf tanah, pembangunan masjid serta perizinannya yang melibatkan bupati sebagai pemerintah daerahnya.

\section{Perwakafan Pasca Kemerdekaan Indonesia}

Setelah kemerdekaan Indonesia, regulasi hukum wakaf mengalami perkembangan yang cukup signifikan yang melalui beberapa fase yaitu:

a. Fase Orde Lama

Pada awal kemerdekaan, undang-undang perwakafan tidak mengalami perubahan dan masih menggunakan aturan Surat edaran produk pemerintahan colonial Belanda. Setelah delapan tahun, tepatnta pada tanggal 22 Desember 1953, pemerintah melalui Departemen Agama mengeluarkan petunjuk-petunjuk mengenai wakaf yang selanjutnya perwakafan menjadi wewenang bagian D (Ibadah Sosial) Jawatan Urusan Agama.

Kemudian keluar surat edaran pada tanggal 8 Oktober 1956 No. 3/D/1956 tentang wakaf yang bukan milik kemasjidan dan surat edaran No. 5/D/1956 tentang prosedur perwakafan tanah. Adanya surat edaran ini merupakan tindak lanjut dari peraturan-peraturan yang kurang mengena tentang peraturan perwakafan. ${ }^{15}$

Pada tahun 1960 lahirlah UU No.5 tentang Peraturan Dasar Pokok-Pokok Agraria yang lebih dikenal dengan UUPA, diundangkan pada tanggal 24 September 1960 yang memberikan kewenangan terhadap Negara untuk melindungi harta wakaf.

Dalam pasal 49 ayat (1) hak milik tanah badan-badan keagamaan dan social sepanjang dipergunakan untuk usaha dalam bidang keagamaan dan social, diakui dan dilindungi.

15 Departemen Agama Ditjen Bimas Islam, Strategi Pengamanan Tanah W akaf (Jakarta: Depag-RI, 2000), hlm. 28 
Badan-badan tersebut dijamin pula akan memperoleh tanah yang cukup dan untuk bangunan dan usahanya dalam keagamaan dan social.

Ayat (2) untuk keperluan peribadatan dan keperluan suci lainnya sebagai dimaksud dalam pasal 14 dapat diberikan tanah yang dikuasai langsung oleh Negara dengan hak pakai. Ayat (3) dikatakan bahwa perwakafan tanah milik dilindungi dan diatur menurut peraturan pemerintah. Akan tetapi, peraturan pemerintah yang diamanahkan ini tidak kunjung hadir bahkan sampai berlalu selama tujuh belas tahun. ${ }^{16}$

b. Fase Orde Baru

Setelah lebih dari tujuh belas tahun, amanat pasal 49 ayat (3) UU No.5 tahun 1960 yang menugaskan pemerintah agar mengatur perwakafan dalam sebuah peraturan pemerintah, akhirnya lahir Peraturan Pemerintah Nomor 28 Tahun 1977 tantang Perwakafan Tanah Milik yang dimuat dalam Lembaran Negara RI Nomor 38 Tahun 1977, Tambahan Lembaran Negara Nomor 3107 yang diundangkan pada tanggal 17 Mei 1977.

Peraturan Pemerintah tersebut terdiri dari 7 bab dan 18 pasal yang meliputi ketentuan umum, yang didalamnya meliputi pengertian wakaf, wakif, ikrar dan nazir, fungsi wakaf yang memuat tentang unsur dan syarat-syarat wakaf, wakif dan nazir, hak dan kewajibannya, termasuk penghasilan dan fasilitas dari hasil kerjanya, tatacara wakaf dan pendaftarannya termasuk wakaf tanah milik, perubahan, penyelesaianperselisihan dan pengawasan perwakafan tanah milik, ketentuan pidana dan ketentuan peralihan serta ketentuan penutup.

Sejauh ini, pengaturan wakaf masih terkait dengan benda-benda tetap (baqa' ainuhu) dan belum menyentuh

16 Sudirman, Regulasi Wakaf di Indonesia, de Jure, Jurnal Syariah dan Hukum vol.6 No.2 Desember 2014, hlm.194

Tasyri': Journal of Islamic Law, 
wakaf benda bergerah (al-manqul) hal ini dapat difahami, karena lahirnya PP ini merupakan amanat dari UU No.5 tahun 1960 yang masih membahas Peraturan Dasar PokokPokok Agraria. ${ }^{17}$

Dengan berlakunya PP tersebut, ketentuan perwakafan dijaman colonial yang tertuang dalam empat edaran Bijblad, jika terdapat pertentangan dengan peraturan ini, maka akan dengan sendirinya menjadi tidak dapat berlaku kembali.

Sebagai tindak lanjut dari PP tersebut, Departemen Agama dan Departemen Dalam Negeri serta beberapa instansi terkait membuat berapa kesepakatan berkenaan dengan pelaksanaan PP tersebut, diantaranya:

1) Peraturan Menteri Dalam Negeri Nomor 6 tahun 1977 tanggal 26 Nopember 1977 tentang Tata Cara Pendaftaran Tanah mengenai perwakafan Taanah Milik.

2) Peraturan Menteri Agama Nomor 1 tahun 1978 tentang Peraturan Pelaksanaan Peraturan Pemerintah Nomor 28 tahun 1977 tentang Perwakafan Tanah Milik.

3) Instruksi Bersama antara Menteri Agama dan Menteri Dalam Negeri Nomor 1 tahun 1978 tentang Pelaksanaan PP Nomor 28 Tahun 1977 tentang perwakafan tanah milik.

4) Keputusan Menteri Agama No.73 tahun 1978 tentang pendelegasian wewenang kepada kakanwil DEPAG Propinsi/setingkat diseluruh Indonesia untuk mengangkat/memeberhentikan setiap kepala KUA Kecamatan sebagai PPAIW.

5) Instruksi Menteri Agama No.3 tahun 1979 tentang juklak Menag No.73 tahun 1978 tersebut.

17 HE. Syibli Syarjaya, Perkembangan Perwakafan dalam perundangundangan di Indonesia, Jurnal Al-Qalam vol.26 No.2 (Mei-Agustus 2009), hlm. 253

Tasyri': Journal of Islamic Law, 
6) Instruksi Menteri Agama No.3 tahun 1987 tentang bimbingan dan pembinaan Kepala Badan Hukum Keagamaan Sebagai Nadzir dan Badan Hukum Keagamaan yang Memiliki Tanah.

7) Keputusan Menteri Agama No. 326 tahun 1989 tentang pembentukan tim Koordinasi Penertiban Tanah Wakaf seluruh Indonesia tingkat pusat.

8) Instruksi Menteri Agama No.15 tahun 1989 tentang Pembuatan Akta Ikrar Wakaf dan Persertifikatan Tanah Wakaf.

9) Keputusan Menteri Agama No.126 tahun 1990 tentang penyempurnaan nomor 7 .

10) Keputusan Menteri Agama No. 196 tahun 1991 tentang penyempurnaan nomor 9.

11) Instruksi bersama Menteri Agama dan Kepala Badan Pertanahan Nasional Nomor 4 tahun 1990 tentang sertifikasi tanah wakaf.

12) Keputusan Dirjen Bimas Islam dan Urusan Haji No.15 tahun 1990 tentang penyempurnaan formulir dan Pedoman Pelaksanaan Peraturan-Peraturan tentang Perwakafan Tanah Milik.

13) Surat Dirjen Bimas Islam dan Urusan Haji No. DII/5/Ed/07/1981 tentang pendaftaran Perwakafan Tanah Milik.

14) Surat Dirjen Bimas Islam dan Urusan Haji NO. DII/5/Ed/II/1981 tentang Petunjuk Pengisian Nomor pada Formulir Perwakafan Taanah Milik.

15) Surat Dirjen Bimas Islam dan Urusan Haji No. DII/55/1/KU.03.2/363/1986 tentang Bea Materai, Akta Nikah, Akta Ikrar Wakaf dan sebagainya dengan lampiran rekaman Surat Dirjen Pajak No.5.40 I/Pj.3/1986 tentang hal tersebut. 
16) Surat Edarana Dirjen Bimas Islam dan Urusan Haji No. DII/5/HK/007/901/1989 tentang Petunjuk Perubahan Status/ Tukar-menukar Tanah Wakaf.

17) Surat Edaran Dirjen Bimas Islam dan Urusan Haji No.D/Ed/BA.03.2/1990 tentang Juknis Instruksi Menteri Agama No.15 tahun 1989 tentang Pembuatan Akta Ikrar Wakaf dan Pensertifikatan Tanah Wakaf.

18) Surat Dirjen Bimas Islam dan Urusan Haji No. DII/5/HK/004/2981/1990 tentang Pejabat yang menandatangani keputusan tentang tim koordinasi Penerbitan Tanah Wakaf Tingkat Propinsi dan Tingkat Kabupaten/Kotamadya.

19) Surat Edaran Dirjen Bimas Islam dan Urusan Haji No.D/Ed/KU.03.1/03/1990 tentang Penempatan Material Tempel pada Blanko Waakaf dengan Rekaman surat Dirjen Pajak No.5.165/pj.5.3/1990 perihal Bea Materai, Akta Nikah, akta Ikrar Wakaf, dan sebagainya.

20) Peraturan Kepala Badan Pertanahan Nasional No.2 tahun 1992 tentang biaya pendaftaran tanah kepada Badan Pertanahan Nasional. ${ }^{18}$

Pada fase ini pula tebitlah Instruksi Presiden No.1 tahun 1991 tentang Kompilasi Hukum Islam (KHI). Inpres ini membawa beberapa pembaharuan dalam pengelolaan wakaf yang merupakan elaborasi dari PP Nomor 28 tahun 1977. Pembaharuan ini mengarah kepada unifikasi madzhab dan hukum Islam yang berlaku di Indonesia. ${ }^{19}$

Perwakafan dalam KHI ini ditempatkan pada Buku III dari pasal 215 sampai 228. Sedangkan pasal 229 merupakan ketentuan penutup yang mengharuskan para hakim dalam menyelesaikan perkara yang diajukan kepadanya wajib

18 Farid Wajdy dan Mursyid, Wakaf dan Kesejabteraan Umat (filantropi Islam yang hampir terlupakan) (Yogyakarta: Pustaka Pelajar, 2007), hlm. 48-50

19 Sholikhul Hadi, Regulasi UU NO 41 tabun 2004 tentang wakaf, Jurnal Penelitian, vol.8, Agustus 2014 hlm. 322 
untuk memperhatikan nilai-nilai hukum yang hidup dalam masyarakat, Meskipun hadirnya KHI merupakan elaborasi PP Nomor 28 tahun 1977, akan tetapi ada beberapa hal yang memebedakan keduanya, diantaranya:

a) Objek wakaf pada KHI lebih luas sebagaimana pada pasal 215 ayat (1) wakaf adalah perbuatan hukum seseorang atau kelompok orang atau badan hukum yang memisahkan sebagian dari benda miliknya dan melembagakannya untuk selama-lamanya guna kepentingan ibadat atau keperluan hukum lainnya sesuai dengan ajaran Islam, dan ayat (4) benda wakaf adalah segala benda, baik benda bergerak atau tidak bergerak yang memiliki daya tahan yang tidak hanya sekali pakai dan bernilai menurut ajaran agama Islam.

b) KHI mengatur beberapa aturan yang belum ada pada PP Nomor 28 tahun 1977 seperti pembatasan jumlah Nadzir sekurang-kurangnya 3 orang dan sebanyakbanyaknya 10 orang yang diangkat oleh Kepala KUA Kecamatan atas saran MUI Kecamatan dan Camat setempat, ditambah adanya pengawasan terhadap pelaksanaan tugas dan tanggung jawab nazir.

c) Dengan demikian, mulai ada kebijakan kebolehan wakaf dengan benda bergerak serta adanya pemberian peranan yang lebih luas terhadap MUI Kecamatan beserta camatnya.

\section{B. Konstitusi Perwakafan di Indonesia}

\section{Undang-Undang no 41 tahun 2004}

Adanya pembahasan tentang kebolehan wakaf atas benda bergerak dalam KHI ternyata belum secara terperinci membahas macam-macam benda bergerak apa saja yang dibolehkan untuk dijadikan barang wakaf, serta berapa banyaknya benda milik yang boleh untuk diwakafkan. Begitu 
juga belum ada rincian tentang hak dan kewajiban nazir secara spesifik.

Bergulirnya pembahasan tentang wakaf tunai oleh seorang ekonom berkebangsaan Bangladesh bernama Prof.A.Mannan yang berhasil mengembangkan wakaf tunai sebagai instrument finansial, keuangan social dan perbankan social (social finance and voluntary sector banking) pada tahun 1995 dinegaranya sehingga mampu mengelola wakaf secara produktif, menginisiasi Direktorat Pengembangan Zakat dan Wakaf Departemen Agama RI untuk mengirimkan surat bernomor Dt. III/5/BA.03.2/2722/2002 tertanggal 26 April 2002 kepada MUI mengenai permohonan fatwa tentang wakaf uang (cash waqf).

Ide pembentukan Badan Wakaf Indonesia yang diusulkan secara langsung oleh menteri Agama RI, Prof.Dr. H.Said Agil Al-Munawwar kepada presiden Megawati Soekarno Putri. Dalam ususlan tersebut diberikan landasan pemikiran yaitu dalam kaitan pengelolaan produktif dengan berkembangnya wacana cash waqf atau wakaf tunai (uang) dan sejenisnya.

Pada tanggal 28 Shafar 1423H/ 11 Mei 2002 keluarlah fatwa MUI tentang wakaf uang yang ditandatangani oleh Ketua Komisi Fatwa KH. Ma'ruf Amin dan Sekretaris Fatwa Hasanudin dengan isi fatwa antara lain bahwa wakaf uang hukumnya adalah Jawaz (boleh). ${ }^{20}$ dengan syarat hanya boleh disalurkan dan digunakan untuk hal-hal yang dibolehkan oleh syar'I serta nilai pokok wakaf uang harus dijamin kelestariannya, tidak boleh dijual, dihibahkan, dan atau diwariskan. ${ }^{21}$

${ }^{20}$ Direktorat Pengembangan Zakat dan Wakaf Ditjen Bimas Islam dan Penyelenggaraan Haji Depag RI, Proses Lahirnya UU No 41 tahun 2004 tentang Wakaf (Jakarta, 2000), hlm. 8

${ }^{21}$ KH. Ma'ruf Amin dkk, Himpunan Fatwa MUI sejak 1975 (Jakarta; Erlangga, 2011), hlm. 424

Tasyri': Journal of Islamic Law, 
Secara langsung, fatwa MUI ini telah melegitimasi pengembangan wakaf terutama wakaf uang sehingga Direktorat pengembangan zakat dan wakaf Depag RI mengusulkan pembentukan Badan Wakaf Indonesia (BWI) kepada Presiden Megawati Soekarno Putri melalui surat No. MA/320/2002 tetanggal 5 September 2002 yang membuahkan pengiriman suart izin prakarsa penyusunan draft RUU tentang wakaf. ${ }^{22}$

Proses pembuatan draft RUU ini mengalami proses yang panjang dan ditangani oleh beberapa pakar perwakafan serta beberapa ormas Islam yang terlibat dalam pembuatannya. Akhirnya pada tanggal 9 Juli 2004 RUU tentang wakaf ini disidangkan dalam rapat DPR dan disahkan dalam waktu 4 bulan serta di sahkan pada tanggal 27 Oktober 2004, satu pekan setelah Presiden Susilo Bambang Yudhoyono menjabat sebagai Presiden RI ke-enam. RUU tentang wakaf ini diundangkan menjadi UU RI Nomor 41 tahun 2004 tentang wakaf yang diundangkan oleh Menteri Sekretaris Negara, Prof. Dr. Yusril Ihza Mahendra dan dicatat dalam Lembaran Negara RI tahun 2004 Nomor 159, Tambahan Lembaran Negara RI nomor 4459. ${ }^{23}$

Beberapa hal baru yang merupakan pengembangan fikih wakaf yang terdapat dalam UU tersebut antara lain:

1) Ada pembahan nazir secara lengkap baik persyaratan, tugas bahkan imbalan yang akan diperolehnya yang terdapat pada pasal 12. Dalam pasal tersebut dinyatakan bahwa nazir dapat

22 Direktorat Pengembangan Zakat dan Wakaf Ditjen Bimas Islam dan Penyelenggaraan Haji Depag RI, Proses Lahirnya UU No 41 tahun 2004 tentang Wakaf (Jakarta, 2000), hlm.10

23 Surat Ketua DPR RI kepada Presiden RI, Nomor: RV.01/5254/DPR RI/2004, Perihal: Persetujuan DPR RI terhadap RUU Wakaf dalam Rapat Paripurna Terbuka ke-7 DPR RI Masa Sidang 2004-2005, tertanggal 28 September 2004 
menerima imbalan dari hasil bersih atas pengelolaan dan pengembangan harta benda wakaf yang besarnya tidak melebihi $10 \%$.

Tentang persoalan hak nazir mendapat upah ini, para Ulama menyebutkan beberapa dalil diantaranya adalah:

"Dari Ibnu Umar ra, ia berkata: "Bahwa sahabat Umar ra, memperoleh sebidang tanah di Khaibar, kemudian Umar ra, menghadap Rasulullah SAW untuk meminta petunjuk"

Umar bin Khattab berkata:

"Wahai Rasulullah SAW, aku mendapat sebidang tanah di Khaibar, aku tidak pernah mendapatkan harta yang menyenangkan hatiku sebelumnya seperti ini, maka apa yang engkau perintahkan kepadaku (atas harta ini)?".

Rasulullah SAW bersabda yang artinya:

"Jika kamu berkenan, tahanlah pokoknya dan sedekahkan (hasilnya), tidak dijual, tidak dihibahkan, dan tidak diwariskan. Ibnu Umar berkata: "Umar menyedekahkannya (hasil pengelolaan tanah) kepada orang-orang fakir, kaum kerabat, hamba sahaya, sabilillah Ibnu sabil, dan tamu, dan tidak dilarang bagi yang mengelola (nazhir) wakaf makan dari hasilnya dengan cara yang baik (sepantasnya) atau memberi makan orang lain dengan tidak bermaksud menumpuk harta" (HR. Bukhari, H:2737 dan Muslim, H:1632)

2) Pembahasan mauquf (benda yang akan di wakafkan) dan peruntukan harta wakaf (mauquf alaih) Serta pembahasan tentang wakaf benda bergerak baik berupa uang, saham dan surat berharga, hak atas kekayaan intelektual, hak sewa dan lainnya, terdapat dalam pasal 28.

3) Adanya Badan Wakaf Indonesia (BWI) yaitu lembaga yang secara khusus bertugas memajukan 
dan mengembangkan perwakafan, membina nazir dalam mengelola dan mengembangkan harta benda wakaf, mengelola benda wakaf yang berskala nasional maupun internasional, memberikan persetujuan dan/atau ijin atas perubahan peruntukan dan status harta benda wakaf, memberhentikan dan mengganti nazir, memberikan persetujuan atas penukaran harta benda wakaf, memberikan saran dan pertimbangan kepada pemerintah dalam penyusunan kebijakan di bidang perwakafan.

4) Wakaf dalam jangka waktu tertentu. Pasal 1 ayat (1) menyebutkan, wakaf adalah perbuatan hukum wakif untuk memisahkan dan/ atau menyerahkan sebagian harta benda miliknya untuk dimanfaatkan selamanya atau untuk jangka waktu tertentu sesuai dengan kepentingannya, guna keperluan ibadah dan/ atau kesejahteraan umum menurut Islam.

Mayoritas pembaharu fiqih lebih condong kepada pendapat Malikiyyah yang men-sahkan adanya wakaf sementara, seperti Abu Zahra dan Mustafa AZ-Zarqa. Menurut madzhab Maliki, harta wakaf memang tidak boleh dimanfaatkan (di-tasharrufkan) oleh wakif selama masa wakaf. Namun bila sudah selesai masanya, wakif berhak untuk menggunakan harta benda tersebut seperti sediakala. ${ }^{24}$

5) Ketentuan pidana dan sanksi administrativ. Pasal 67 menyebutkan, setiap orang yang dengan sengaja menjaminkan, menghibahkan, mewariskan dan mengalihkan dalam bentuk pengalihan hak

${ }^{24}$ Wahbah az-Zuhaili, al-Fiqh al-Islam wa Adillatubu, (Beirut: Dar alfikr, tt) hlm. 154 
lainnya harta benda wakaf yang telah diwakafkan sebagaimana dimaksud dalam pasal 40 atau tanpa izin menukar harta benda wakaf yang telah diwakafkan sebagaimana dimaksud dalam pasal 41, dipidana dengan penjara paling lama 5 (lima) tahun dan/atau pidana denda Rp. 500.000.000 (lima ratus juta rupiah).

Ketentuan hukuman ini merupakan bentuk hukuman ta'zir ${ }^{25}$ sebab hukuman bagi orang yang menyalahgunakan harta wakaf tidak dibahas secara ekspisit di dalam Al-Qur'an maupun Hadits. Oleh karena itu penegasan melaui UU No 41 tahun 2004 ini setidaknya mampu memberikan peringatan sejak dini terhadap pelanggaran tersebut.

Lahirnya Undang-Undang perwakafan ini setidaknya merupakan penyempurnaan dari peraturan-peraturan sebelumnya dengan menambah hal-hal baru sebagai upaya pemberdayaan wakaf secara produktif dan professional, sehingga dapat mendukung kesejahteraan social-ekonomi umat Islam secara khusus dan bangsa Indonesia pada umumnya.

Wakaf produktif adalah bentuk transformasi dari pengelolaan wakaf secara professional untuk meningkatkan atau menambah manfaat wakaf. Pengelolaan secara cermat terhadap modal yang minimum untuk menghasilkan barang atau jasa yang maksimum. ${ }^{2}$ Pemberdayaan wakaf produktif yang mulai Nampak dengan bergulirnya undang-undang perwakafan tersebut sangat berdimensi social, yang semata-

25 Ta'zir adalah hukuman ysng dijatuhkan atas kebijaksanaan hakim, karena tidak terdapat dalam Nash Al-Qur,an maupun Hadits. Pendapat lain mengatakan bahwa ta"zir adalah hukuman untuk pelaku dosa besar yang tidak diatur dalam Hudud atau lainynya. lihat Ahmad Hanafi: Asas-Asas Hukum Pidana Islam (Jakarta: Bulan Bintang, 2005)hlm. 268

26 Jaih Mubarok, Wakaf Produktif, (Bandung: Simbiosa Rekatama Media, 2008) hlm. 15 
mata mengabdikan diri untuk kemaslahatan umat Islam. Sehingga yang tampak dari itu adalah Nampak pro kemanusiaan (hablun minannas), bukan sekedar wakaf yang hanya berdimensi ketuhanan saja (hablun minAllah). ${ }^{27}$

Konteks kelahiran dan motif terpenting regulasi undang-undang perwakafan adalah untuk meningkatkan kesejahteraan ekonomi dan penguatan masyarakat sipil dengan memanfaatkan sumber-suber alternative yang sangat potensial yang ada dalam wakaf. 28

Apabila mencermati penjelasan umum undang-undang Nomor 41 Tahun 2004 tersebut, akan Nampak dua alasan kuat yang memotori lahinya uu tersebut, yaitu pertama bahwa tujuan Negara Kesatuan Republik Indonesia adalah memajukan kesejahteraan umum. Untuk mencapai tujuan tersebut, perlu menggali pranata keagamaan yang memiliki manfaat secara ekonomis, yaitu wakaf. Yang kedua, praktik wakaf yang sudah lama berjalan dimasyarakat belum sepenuhnya tertib dan efisien, seperti ditemukannya beberapa tanah wakaf yang kurang dimanfaatkan dengan semestinya, serta beberapa kasus beralihnya harta wakaf kepada pihak ketiga.

Undang-undang no 41 tahun 2004 terdiri dari $11 \mathrm{Bab}$ dan 71 pasal. Bab 1 adalah ketentuan umum yang hanya terdiri dari satu pasal yang meliputi : pengertian wakaf, wakif, ikrar wakaf, nazir, harta benda wakaf, Pejabat Pembuat Akta Ikrar Wakaf, Badan Wakaf Indonesia, pemerintah dan menter.

Bab 2 berisi dasar-dasar wakaf terdiri atas sepuluh bagian dan 30 pasal: (1) umum: keabsahan dan keterikatan wakaf, (2) tujuan dan fungsi wakaf, (3) unsur-unsur wakaf, (4)

27 Abdurrahman Kasdi: Fiqih Wakaf (Yogyakarta: Idea Press, 2013),

28 Tuti A. Najib dan Ridwan Makassary (ed)Wakaf, Tuban dan Agenda Kemanusiaan, (Jakarta:TFF dan CSRC, 2006), hlm. 28 
wakif, (5)nazir, (6) harta benda wakaf, (7) ikrar wakaf, (8) peruntukan harta benda wakaf, (9) wakaf dengan wasiat, dan (10) wakaf benda bergerak.

Bab 3 terdiri dari 8 pasal yang mengatur tentang peraturan pendaftaran benda wakaf, PPAIW, penukaran dan pengubahan peruntukan benda wakaf. Bab 4 berisi tentang larangan-larangan yang menyangkut benda wakaf dan pengecualiannya.

Bab 5 terdiri dari 5 pasal yang mengatur tentang kewajiban nazir, pengelolaan harta benda wakaf harus sesuai dengan syari'ah, larangan bagi nazir, pemberhentian dan penggantian nazir, dan pengembangan benda wakaf.

Bab 6 berisi tentang aturan Badan Wakaf Indonesia (BWI) terdiri atas 6 bagian dan 15 pasal: (1)Kedudukan dan Tugas BWI, (2) Organisasi BWI, (3) Anggota BWI, (4)Pengangkatan dan pemberhentian anggota BWI,(5)Pembiayaan BWI (6) pertanggung jawaban BWI.

$\mathrm{Bab} 7$ berisi tentang penyelesaian sengketa yang terdiri dari satu pasal yang membahas tentang asas musyawarah dalam penyelesaian sengketa wakaf, atau melalui mediasi, arbritase atau melalui pengadilan.

Bab 8 berisi tentang pembinaan dan pengawasan oleh menteri yang melibatkan BWI serta dapat bekerjasama dengan pihak lain termasuk dapat menggunakan akuntan publik. Bab 9 berisi tentang aturan ketentuan pidana dan sanksi administratif.

Bab 10 berisi tentang peraturan peralihan yang mengaturtentang keabsahan wakaf yang dilakukan sebelum diundangkannya UU No 41 tahun 2004 ini dan masih tetap berlakunya peraturan perundang-undangan yang lama sepanjang tidak bertentangan dengan UU ini.

Bab 11 berisi tentang ketentuan penutup yang menyatakan bahwa undang-undang ini mulai berlaku sejak tanggal diundangkannya yakni 27 Otober 2004. 


\section{Peraturan Pemerintah Nomor 42 Tahun 2006}

Untuk melaksanakan amanat UU Nomor 41 tahun 2004 pemerintah menerbitkan Peraturan Pemerintah Nomor 42 tahun 2006 tentang pelaksanaan UU sebelumnya tersebut yang ditetapkan pada tanggal 15 Desember 2006 dan dimuat dalam Tambahan Lembaran Negara Republik Indonesia Nomor 4667. PP ini terdiri dari 11 bab, 10 bagian dan 61 pasal yang pada dasarnya merupakan penjabaran dalam rangka pelaksanaan UU Nomor 41 tahun 2004.

Lahirnya Undang-undang serta peraturan pemerintah tersebut bertujuan untuk memberikan pijakan hukum yang pasti, kepercayaan publik serta perlindungan terhadap asset masyarakat. Yang kesemuanya itu menuju pada pemberdayaan wakaf produktif dengan tujuan utama mencapai amanat UUD 1945 yaitu mencapai kesejahteraan umum.

Sangat besarnya keutamaan dan manfaat wakaf bagi kehidupan masyarakat dan peningkatan taraf hidup serta kesejahteraan berbangsa dan bernegara , jika didayagunakan dengan baik maka kesejahteraan umat bukanlah menjadi hal yang mustahil. Direktorat Pemberdayaan Wakaf DEPAG RI, sampai tahun 2009 mencatat bahwa asset tanah wakaf yang terdata diseluruh Indonesia adalah 2.719.854.759,72 meter persegi yang bearda pada 367.438 lokasi. $75 \%$ diantaranya sudah bersertifikat wakaf dan $10 \%$ nya mempunyai potensi ekonomi tinggi. ${ }^{29}$

Regulasi undang-undang perwakafan menunjukkan keseriusan pemerintah dalam memperhatikan kelembagaan wakaf dan mengindikasikan kesungguhan pemerintah untuk memperkokoh lembaga hukum Islam menjadi hukum nasional dalam bentuk transformasi hukum ${ }^{30}$

\footnotetext{
${ }^{29}$ Direktorat Pemberdayaan Wakaf Depag RI, 2009

${ }^{30}$ Abdurrahman Kasdi, Fiqih Wakaf (Yogyakarta: Idea Press, 2013),
} hlm.124 


\section{PENUTUP}

Wakaf adalah salah satu pranata ibadah yang mempunyai dimensi religious dan sosial yang sudah dikenal masyarakat Indonesia bersaman dengan masuknya agama Islam di Indonesia. Sebagai salah satu lembaga Islam, wakaf telah menopang perkembangan dan kemajuan agama dan masyarakat Islam dengan banyaknya rumah-rumah ibadah serta lembaga pendidikan Islam yang tumbuh subur bahkan sebelum kemerdekaan.

Munculnya berbagai peraturan wakaf pasca kemerdekaan Indonesia sarat adanya regulasi yang mampu menyeimbangkan antara hukum Islam dan positif yang berlaku di Indonesia. Jika UU Nomor 5 tahun 1960 adalah tonggak awal regulasi hukum wakaf, maka UU Nomor 41 tahun 2004 dapat dikatakan sebagai undang-undang termutakhir yang mampu menjawab tantangan zaman sekaligus mampu mengemban amanat UUD 1945 tentang memajukan kesejahteraan umum.

Dalam tinjauan ekonomi, UU Nomor 41 tahun 2004 memiliki latar belakang serta tujuan untuk pemberdayaan wakaf produktif guna kemaslahatan kesejahteraan social. Sedangkan dalam pandangan agama, UU tersebut merupakan terobosan baru dalam Fikih wakaf yang menuju pada fikih yang dinamis dan kontekstual.

\section{DAFTAR PUSTAKA}

Al-Kabisi, Muhammad Abid, Hukum wakaf, Jakarta IIMAN, 2003.

Amin, KH. Ma'ruf dkk, Himpunan Fatwa MUI sejak 1975(Jakarta; Erlangga, 2011.

Asni, Pengembangan Hukum Perwakafan di Indonesia, Jurnal Al'Adl, vol.7 No.2, Juli 2014.

Az-Zuhaili, Wahbah, al-Figh al-Islam wa Adillatuhu, Beirut: Dar alfikr, t.t. 
Direktorat Pengembangan Zakat dan Wakaf Ditjen Bimas Islam dan Penyelenggaraan Haji Depag RI, Proses Lahirnya UU No 41 tahun 2004 tentang Wakaf. Jakarta, 2000.

Djatnika, Rahmat, Pandangan Islam tentang Infak, Shadaqah, Zakat dan Wakaf Surabaya: al-Ikhlas, 1982.

Djunaidi, Achmad. dkk, Perkembangan Pengelolaan Wakaf Di Indonesia, Jakarta: Direktorat Pemberdayaan Wakaf, 2006.

Hadi, Solikhul, Regulasi UU NO 41 tahun 2004 tentang wakaf, Jurnal Penelitian, vol. 8, Agustus 2014

Kasdi, Abdurrahman, Fiqih Wakaf, Yogyakarta: Idea Press, 2013.

Mubarok, Jaih, Wakaf Produktif, Bandung: Simbiosa Rekatama Media, 2008.

Muslim, Imam, Shahih Muslim. Surabaya:al-Haramain,t.t.

Sokanto, Surjono, Hukum Adat Indonesia, Jakarta: CV. Rajawali, 1981.

Suhadi, Imam, Wakaf untuk Kesejahteraan Umat, Yogyakarta: PT. Dana Bakti Prima Yasa, 2002.

Syuja',Abu Ahmad al-Asfahani, Ghayah wa at-Taqrib, Semarang: CV. Toha Putra, tt.

Wajdy, Farid dan Mursyid, Wakaf dan Kesejahteraan Umat (filantropi Islam yang hampir terlupakan) Yogyakarta: Pustaka Pelajar, 2007. 
Tasyri' Journal of Islamic Law, Vol. 1 No. 1, Januari 2022

Tasyri': Journal of Islamic Law,

Prodi Ahwal al-Syakhshiyyah STAI Nurul Iman Parung-Bogor

Page 129 
Tasyri' Journal of Islamic Law, Vol. 1 No. 1, Januari 2022

Tasyri': Journal of Islamic Law,

Prodi Ahwal al-Syakhshiyyah STAI Nurul Iman Parung-Bogor

Page 130 